\title{
АСПЕКТЫ ПРЕПОДАВАНИЯ ДОМАШНЕГО ЧТЕНИЯ НА УРОКАХ АНГЛИЙСКОГО ЯЗЫКА В ВУЗЕ (НА ПРИМЕРЕ РОМАНА НИКА ХОРНБИ «МОЙ МАЛЬЧИК»)
}

\section{ASPECTS OF TEACHING HOME READING IN ENGLISH LESSONS AT THE UNIVERSITY (THROUGH THE EXAMPLE OF THE NOVEL "ABOUT A BOY" BY NICK HORNBY) \\ D. Peshkova}

Summary: The article examines the aspects of teaching home reading at the university. The author describes the examples of exercises at the prereading, reading and post- reading stage. Various methods of working with the vocabulary are considered. Some forms of work with the wordsrealia, contributing to forming the social and cultural competence, are mentioned.

Keywords: home reading, pre-reading stage, reading stage, post-reading stage, individual work.
$\mathrm{B}$ соответствии с ФГОС ВО по направлению подготовки 44.03.01 «Педагогическое образование» бакалавр должен обладать способностью к самоорганизации и саморазвитию, а именно компетенцией УК-6, В соответствии с которой необходимо «управлять своим временем, выстраивать и реализовывать траекторию саморазвития на основе принципов образования в течение всей жизни» [5].

Самостоятельная работа студентов является неотьемлемым компонентом образовательного процесса в высшем учебном заведении. Важно, чтобы студенты не просто приобретали знания, но и умели их «добывать» $[6 ; 121]$. В самостоятельной работе заложен огромный потенциал, способствующий расширению и углублению знаний студентов, формированию творческих способностей, а также интереса к учебно-познавательной и практической профессиональной деятельности [4; 122].

Домашнее чтение является ярким примером самостоятельной работы, которой занимаются студенты языковых факультетов. Домашнее чтение - это «зрелое» чтение, которое носит коммуникативный характер и предполагает владение разными видами и стратегиями чтения. Процесс работы над оригинальными художественными произведениями зарубежной литературы, как правило, выстраивается так, что в ходе его студенты учатся вести дискуссии по данной проблеме, рассуждать и аргументировать свою точку зрения [1;144].
Пешкова Дарья Юрьевна

Старший преподаватель, Елецкий Государственный Университет им. И.А. Бунина

Daryanewreality@yandex.ru

Аннотация: В статье рассматриваются аспекты преподавания домашнего чтения в вузе. Автор описывает примеры упражнений на дотекстовом, текстовом и послетекстовом этапе. Рассмотрены разные методы работы с лексикой. Перечислены некоторые формы работы с реалиями, способствующими формированию страноведческой компетенции.

Ключевые слова: домашнее чтение, дотекстовый этап, текстовый этап, послетекстовый этап, самостоятельная работа.

В век технологий и интернета большинство молодых людей предпочитают социальные сети и компьютерные игры книгам. В этой связи необходим правильный отбор текстов для домашнего чтения. Тексты должны быть актуальными, современными, познавательными, информативными, интересными для молодежи. Также они должны соответствовать целям и задачам обучения, и уровню подготовки учащихся [2; 38-43].

В институте филологии ЕГУ им. И.А. Бунина мы со студентами 1-го курса, обучающимися по направлению подготовки 44.03.05 Педагогическое образование (профиль Иностранный язык (английский), Иностранный язык (китайский)) в связи с увеличением количества часов в 2021-2022 году проводим занятия по домашнему чтению на регулярной основе, 1 раз в 2 недели. Один из романов, который мы читаем - это «About a Boy» («Мой мальчик» писателя Ника Хорнби). Современный роман затрагивает актуальные проблемы человеческих взаимоотношений, дружбы, взаимодействия родителей и детей, проблему неполных семей, буллинга в школе и т.д. Все эти темы лаконично вписываются в рабочую программу, поскольку одна из базовых тем в ней - «семейная жизнь» («Family Life»). Обучающиеся в течение двух недель самостоятельно читают 15-25 страниц и работают над заданием по главам. Для реализации поставленной задачи они нацелены на следующие аспекты изучающего чтения: 
1. восприятие языковых средств и их точное понимание в тексте;

2. извлечение полной (фактической) информации;

3. осмысление извлеченной информации [3; 99].

Поставленные задачи решаются на дотекстовом, текстовом и послетекстовом этапах работы над материалом произведения.

В первую очередь, когда мы знакомимся с новым романом, мы обсуждаем биографию автора и его литературные творения. В конце каждого блока прочитанных глав предполагается пересказ, который мы делаем коллективно, по цепочке добавляя по 1-2 предложения к рассказу одногруппников. В конце обсуждения всего романа проводится анализ произведения по определенной схеме, которая будет указана ниже. Если позволяет время, то мы смотрим фильм, экранизированный по книге, и сравниваем его содержание и сам роман.

На дотекстовом этапе обычно предлагаются задания по поиску английских эквивалентов в тексте. Translate the words into English: парень, непропечённый (о хлебе), каша из кукурузной крупы, бородка клинышком, разбрасывать, измождённый, постигать, нелогичное заключение, самодовольно, без гроша в кармане, разглагольствовать, способность, врождённый талант, опухший, провести расследование, фломастер. Учитывая, что в произведении много незнакомой лексики, акцент ставится на чтении трудных слов по транскрипции: requisite |'rekwIzIt], pervert |pə'vз't|, avuncular |ə'v^џkjulə|, embellishment |Im'belı[mənt], malarkey |mə'la:ki|. Проводится работа по снятию языковых трудностей, например, подбор синонимов к словам и словосочетаниям. Give synonyms to the words: questionnaire, hypothermia, speculation, peek over, clutter, throw, a mug of tea, baggy trousers, demented; crows' feet, bestow forgiveness, withering look, overlap, infidelity; handicapped children, lousy, dearth, litany of treachery and deceit.

На текстовом этапе мы, прежде всего, работаем с дефинициями. Студенты подбирают подходящие определения к словам исходя из контекста и читают предложения из текста, иллюстрирующие их. Give definitions and situations from the text to the words: strike up (a rapport), clincher, come to terms with, hilarious, make headway; fraud, come up with.

Зачастую в задание с дефинициями встречаются идиомы, знание которых необходимо для формирования социокультурной компетенции, например:

burn the candle at both ends - усердно работать, засиживаясь до поздна;

under the weather - нездоровый, больной; take at face value - принять за чистую монету; beat around the bush - ходить вокруг да около; dog's dinner - неразбериха, беспорядок;

let off steam - снять нервное напряжение;

best of both worlds - иметь и то и другое (без необходимости выбора); и рыбку съесть - и косточкой не подавиться;

big break - звездный час;

get the wrong end of the stick - неправильно понять;

in one piece - в целости и сохранности.

Несмотря на то, что разговорную лексику в формальном общении мы избегаем, в заданиях мы касаемся ее и обсуждаем различия в значении. Например, мы затрагиваем большое количество фразовых глаголов (keep out of , get at, kill off , cut up, get round to, mess around, keel over, wade in, fix sb up и т.д.). Интересно то, что в произведении представлено значительное количество лексики, обозначающей странное поведение или недостаток когнитивных способностей: be nuts, go nuts, off colour,thick, barmy и т.д.

На текстовом этапе по каждой главе предлагаются обстоятельные вопросы, которые в дальнейшем помогают воссоздать события в пересказе. Например, вопросы по 1 заданию по главам I-VI выглядят следующим образом:

1. What do we get to know about the major characters in the first chapter?

2. How does Marcus get on with his mother? Is there any estrangement between them?

3. What does Will Freeman consider to be his strong points?

4. Does Will have a desire to establish a family of his own? What is his attitude to children?

5. What is implied by the words: "Jessica wanted to exchange the froth and frivolity for something more solid"?

6. Has Will wholeheartedly agreed to be Imogen's godfather?

7. Why isn't Marcus right for schools? What is queer in his demeanour?

8. What are the reasons for which Marcus has been ridiculed and mocked at by his classmates?

9. Do you approve of Marcus's mother methods of upbringing?

10. Who does Will chat up? Why has he been attracted by a single mother?

11. What makes people think that Will is "the Good Guy, the Redeemer"?

12. What relationship has Will launched into?

13. What is wrong with Marcus's mother?

14. Does Marcus get along with other kids? Does he have the best buddies to hang around?

15. Why does the author say that Marcus's "fame has been spreading?" How have pupils cracked jokes about him?

16. What does Marcus think of this situation at heart if 
he has conjured up such metaphors as "koala bears have with piranha fish", "insults were hurled in just the same way as missiles"?

17. Is Will appropriate for the role of a dad? What story has he thought up?

18. Does Will work like a beaver?

19. Who are the members of SPAT? What is its purpose? Has Will felt at ease there?

На послетекстовом этапе мы обсуждаем разные вопросы, выявляем противоположные точки зрения в диспутах и дискуссиях.

1. Give Marcus's character sketch. Дайте характеристику личных качества Маркуса.

2. Can you call the situation with Marcus as bullying? Who is susceptible to be a despised victim being given a hard time? Можно ли назвать произошедшую с Маркусом ситуацию «буллингом»? Кто может быть жертвой этого явления?

3. Will is an antipode of a person who is as busy as a bee. Does he inspire sympathy to you? Уилл является антиподом трудолюбивого человека. Вызывает ли он симпатию?

4. Is it significant to have such communities as SPAT? What is its purpose? Важно ли иметь такие сообщества как «Родители-одиночки - вместе»?

Мы периодически обращаемся к стилистическим тропам и фигурам речи:

1. Suzie was crying, and then Megan started up too, so in seconds the room had gone from a terrifying silence and stillness to noisy, terrifying panic. - Antithesis антитеза (описание в предложении перехода от тишины к неподвижности и к панике)

2. Marcus felt his insides turn to mush. - Hyperbole преувеличение (все внутри сжалось от страха).

3. He played ball, he blew bubbles, he burst crisp packets (a mistake-many tears, lots of irritated glances), he hid, he sought, he tickled, he dangled... - Repetition (повтор); gradation (градация) [7].

На занятиях мы развиваем страноведческую компетенцию, когда обращаемся к реалиям страны изучаемого языка. Например, вопрос «Who was Florence Nightingale? Why did Will consider her to be a heart of gold?» наталкивает обучающихся на сравнение Уилла с историческим персонажем - добродетельной сестрой милосердия Флоренс Найтингейл. Еще одним полезным для развития кругозора вопросом является обсуждения движения хиппи, к которому принадлежала Фиона: What can уоu say a youth movement "hippy" except the fact that it's "a usually young person who rejects established social customs (such as by dressing in an unusual way or living in a commune) and who opposes violence and war; especially: a young person of this kind in the 1960s and 1970s"?
В произведении важную роль играют музыкальные композиции, потому что они показывают разницу в интересах и образе жизни между главными героями. Мы слушаем и обсуждаем, например, песню «Killing Me Softly With His Song», которую Уилл едва смог вынести в исполнении Маркуса и его мамы Фионы. Еще одной значительной фигурой, связанной с музыкой, является рокмузыкант Курт Кобейн: «Who was Kurt Cobain? Why did his name become the reason for the messing around?»

Особенно существенным аспектом изучения языка являются пословицы. Так, мы интерпретируем пословицы, например, «do as the Romans do» (со своим уставом не ходят) или иллюстрируем их своими ситуациями из жизни. Некоторые главы описывают празднование Рождества, что не может не стать поводом для дискуссии. Например, в тексте дано предложение: «...have Christmas pudding with five-pence pieces hidden in it». Студенты ищут рецепт рождественского торта и обсуждают традицию, когда внутри помещают монетку, наперсток, пуговицу или кольцо, чтобы определить судьбу на будущий год. (Putting a silver coin in the pudding is another age-old custom that is said to bring luck to the person that finds it. In the UK the coin traditionally used was a silver 'six pence'. The closest coin to that now is a five pence piece!)

В конце каждого задания по главам проводится тест на знание лексики из задания с дефинициями. Студентам необходимо корректно перевести предложения, используя изученные слова. Translate the sentences. Define the underlined words:

1. Я не собираюсь навязываться посторонним.

2. Как это благородно с твоей стороны.

3. Неужели это правда? Кто впутал тебя в это?

4. Если незваный гость придет внезапно (= запроcmo) в гости, хозяйка разозлится.

5. Он начвный как ребенок - ему все нужно разжевывать.

6. Почему бы не принять решение спонтанно?

После чтения и обсуждения книги в течение семестра студенты готовят презентацию и анализ произведения по следующему плану:

1. The author's biography;

2. The title;

3. The setting;

4. The subject;

5. The message;

6. The plot;

7. The characters.

8. The conflict: internal and external conflicts.

9. The Vocabulary: emotionally-coloured words; international words; phrasal verbs, proper names, synonyms, antonyms u m.d. 
10. The Stylistic Devices.

11. Conclusion.

Альтернативой анализу произведения может быть написание эссе или сочинений по затрагиваемым в романе вопросам, например, по теме «буллинга»: Write an essay on the point of bullying. What causes bullying? Do you agree that people who are bullying you, are insecure about who they are, and that's why they're bullying you? What should parents, teachers and children do to prevent bulling?

Хорошей возможностью постоянной практики языка является регулярное ведение читательского дневника в социальной сети ВКонтакте. Преподаватель может создать закрытую группу, где студенты смогут обмениваться мыслями, понравившимися идеями и цитатами, реалиями, реферировать прочитанное.
Подводя итог вышесказанному, следует сказать, что нельзя недооценивать важность и пользу домашнего чтения. В силу нехватки часов учителя иногда полностью от него отказываются, тем самым теряя возможность наращивания лексики студентов, повышения их мотивации, привития любви к чтению, развития коммуникативных навыком и навыков самостоятельной работы. Лексика, проработанная тщательным образом, с высокой долей вероятности закрепится в активном запасе, если поощрять студентов постоянно ее использовать в речи. В ходе выполнения заданий на дотекстовом, текстовом и послетекстовом этапах развиваются навыки устной и письменной речи. Обсуждение дискуссионных вопросов вовлекает обучающихся в интеракцию и делает их активными участниками образовательного процесса, а не просто пассивными слушателями.

\section{ЛИТЕРАТУРА}

1. Голенко М.Д. Метод проектов на занятиях по домашнему чтению на факультете иностранных языков // Ярославский педагогический вестник. 2014. №2. Том II (Психолого-педагогические науки). С.143-147. https://cyberleninka.ru/article/n/metod-proektov-na-zanyatiyah-po-domashnemu-chteniyu-nafakultete-inostrannyh-yazykov

2. Киселева 3.А. Творческий подход к домашнему чтению в обучении иностранному языку в вузе // Вопросы методики преподавания в вузе. 2017. Том 6. №23. C. 38-43 https://cyberleninka.ru/article/n/tvorcheskiy-podhod-k-domashnemu-chteniyu-v-obuchenii-inostrannomu-yazyku-v-vuze

3. Маслыко Е.А., Бабинская П.К., Будько А., Петрова С. Настольная книга преподавателя иностранного языка. «Высшая школа». 2004. С. 99

4. Назарова И.В. Организация самостоятельной работы в вузе в целях профессионально-творческого саморазвития студентов// Вестник Поволжского института управления. 2011. № 2. С. 121-127.

5. Приложение. Федеральный государственный образовательный стандарт высшего образования - бакалавриат по направлению подготовки 44.03 .01 Педагогическое образование https://base.garant.ru/71897858/53f89421bbdaf741eb2d1ecc4ddb4c33/

6. Рубаник А.Н., Большакова Г.И., Тельных Н.В. Самостоятельная работа студентов // Высшее образование в России. 2005. № 6. С. 120-124.

7. Nick Hornby. About a Boy. Penguin, 2014.

(c) Пешкова Дарья Юрьевна (Daryanewreality@yandex.ru). Журнал «Современная наука: актуальные проблемы теории и практики» 